\title{
Measuring the Consequences of Delegate Selection Rules in Presidential Nominations
}

\section{Citation}

Ansolabehere, Stephen Daniel, and Gary King. 1990. Measuring the consequences of delegate selection rules in presidential nominations. The Journal of Politics 52(2): 609-621.

\section{Published Version}

doi: $10.2307 / 2131908$

\section{Permanent link}

http://nrs.harvard.edu/urn-3:HUL.InstRepos:4320047

\section{Terms of Use}

This article was downloaded from Harvard University's DASH repository, and is made available under the terms and conditions applicable to Other Posted Material, as set forth at http:// nrs.harvard.edu/urn-3:HUL.InstRepos:dash.current.terms-of-use\#LAA

\section{Share Your Story}

The Harvard community has made this article openly available.

Please share how this access benefits you. Submit a story.

\section{Accessibility}




\title{
Measuring the Consequences of Delegate Selection Rules in Presidential Nominations
}

\author{
Stephen Ansolabehere \\ University of California, Los Angeles \\ Gary King \\ Harvard University
}

In this paper, we formalize existing normative criteria used to judge presidential selection contests by modeling the translation of citizen votes in primaries and caucuses into delegates to the national party conventions. We use a statistical model that enables us to separate the form of electoral responsiveness in presidential selection systems, as well as the degree of bias toward each of the candidates. We find that (1) the Republican nomination system is more responsive to changes in citizen votes than the Democratic system; (2) non-PR primaries are always more responsive than PR primaries; (3) surprisingly, caucuses are more proportional than even primaries held under PR rules; (4) significant bias in favor of a candidate was a good prediction of the winner of the nomination contest. We also (5) evaluate the claims of Ronald Reagan in 1976 and Jesse Jackson in 1988 that the selection systems were substantially biased against their candidates. We find no evidence to support Reagan's claim, but substantial evidence that Jackson was correct.

\section{INTRODUCTION}

ur knowledge of the effects of presidential selection rules derives from a combination of scholarly literature, participant reports, and reformers' pleas. Most writers see selection rules as defining the fairness of the system, controlling the speed with which a presidential nomination is decided, influencing who is nominated, and affecting the outcome of the general election contest in November. The work produced by these writers is quite large, and the historical and contextual detail is impressive. Nevertheless, the normative criteria are often ambiguous and systematic empirical evidence is frequently lacking.

We formalize existing normative criteria used to judge presidential selection contests by modeling the translation of citizen votes in primaries and caucuses into delegates to the national party conventions. We apply our model to data from 1976 to 1988 . Our work thus begins where the studies of primary voting behavior (Bartels 1988), candidate strategies (Aldrich 1980),

The authors gratefully acknowledge NSF grants SES-87-22715 and SES-89-0920I to Gary King and helpful comments from Andrew Gelman.

Journal of Politics, Vol. 52, No. 2, May 1990

(C) 1990 by the University of Texas Press 
and media behavior (Brady and Johnston 1987) in presidential nomination contests leave off. We take voter choice as given and consider how the primary and caucus vote is translated into delegates. This enables us to ascertain the precise effects of delegate selection rules on the fairness and essential character of the parties nominating systems. Our statistical model enables us to judge the fairness of the selection system to individual candidates and ideological programs, as well as to determine the responsiveness of the system to voter preferences.

\section{Clarifying Normative Criteria in Presidential Selection}

In this section, we identify normative criterion in the presidential selection literature, and we simultaneously develop a statistical model that incorporates each and enables us to estimate their levels and directions. Part of an article by Geer $(1986,1007-14)$ is the only previous delegates-votes model of presidential selection rules of which we are aware. As we explain below, responsiveness is a theoretical concept that refers to an entire electoral system, and it discriminates among the candidates only by their relative vote percentages (instead of their names). Unfortunately, Geer allows "responsiveness" and bias to vary from candidate to candidate; he therefore has pure definitions and measures of neither concept. ${ }^{1}$ In spite of these problems, Geer stays close to his data and therefore arrives at several important conclusions, some of which we confirm. Below, we correct for the above problems, introduce a more general statistical model, add Democratic caucus data, and update the analysis to 1988 .

In all of the literature, perhaps the most commonly mentioned, though not universally supported, normative criteria is proportional representation (PR) (Ceaser 1979, 260-304). The basic idea is that national party convention delegates should be allocated in proportion to the votes they receive in a state: Let $V_{i j}$ be the proportion of votes candidate $j$ receives in state $i$. $D_{i j}$ is the proportion of delegates state $i$ allocates to candidate $j$. Then

$$
D_{i j}=V_{i j}
$$

for all candidates $j\left(j=1, \ldots, J_{i}\right)$ competing in state $i(i=1, \ldots, 50)$. However, even if a state counts votes on the statewide level and carefully

\footnotetext{
${ }^{1}$ Geer also purports to measure three concepts-responsiveness, bias, and threshold effects-but since his statistical model includes only two parameters he can only be measuring two of the three (probably the first two). Furthermore, for both statistical reasons (as explained by Brady and Ansolabehere 1988) and intuitive ones (as understood by survey researchers and journalists using "trial heats"), pairwise comparisons is a better way to study multicandidate decision processes than his practice of comparing each candidate with the sum of the others. In addition, since Geer provides no standard errors for his estimates, one cannot tell which is a systematic (and statistically significant) effect and which is due to the usual random fluctuations so common in politics.
} 
tries to allocate delegates proportionally, equation 1 may not hold exactly due to rounding error, applying PR only within congressional districts, using vote thresholds, and other features of presidential selection rules. Thus, as a normative standard, equation $l$ is too strict. Instead, we can think of this allocation rule occurring only in expectation:

$$
E\left(D_{i j}\right)=V_{i j}
$$

This is also portrayed for just two candidates by the 45-degree line in figure 1 .

Whereas dark horse candidates seem to prefer PR, party professionals usually favor systems where the allocation of delegates is very responsive to changes in voter preferences (Sanford 1981; Kirkpatrick, Malbin, Mann, Penniman, and Ranney 1980). A responsive system is one where small changes in voter preferences lead to relatively large changes in candidate support among a state's delegation to the national party convention. Furthermore, a highly responsive nomination system is likely to lead to an early victory by a presidential candidate if votes follow some autoregressive process, as would be described by campaign "momentum" (Bartels 1988), or if voters

\section{Figure 1}

\section{Example Delegate-Votes Curves}

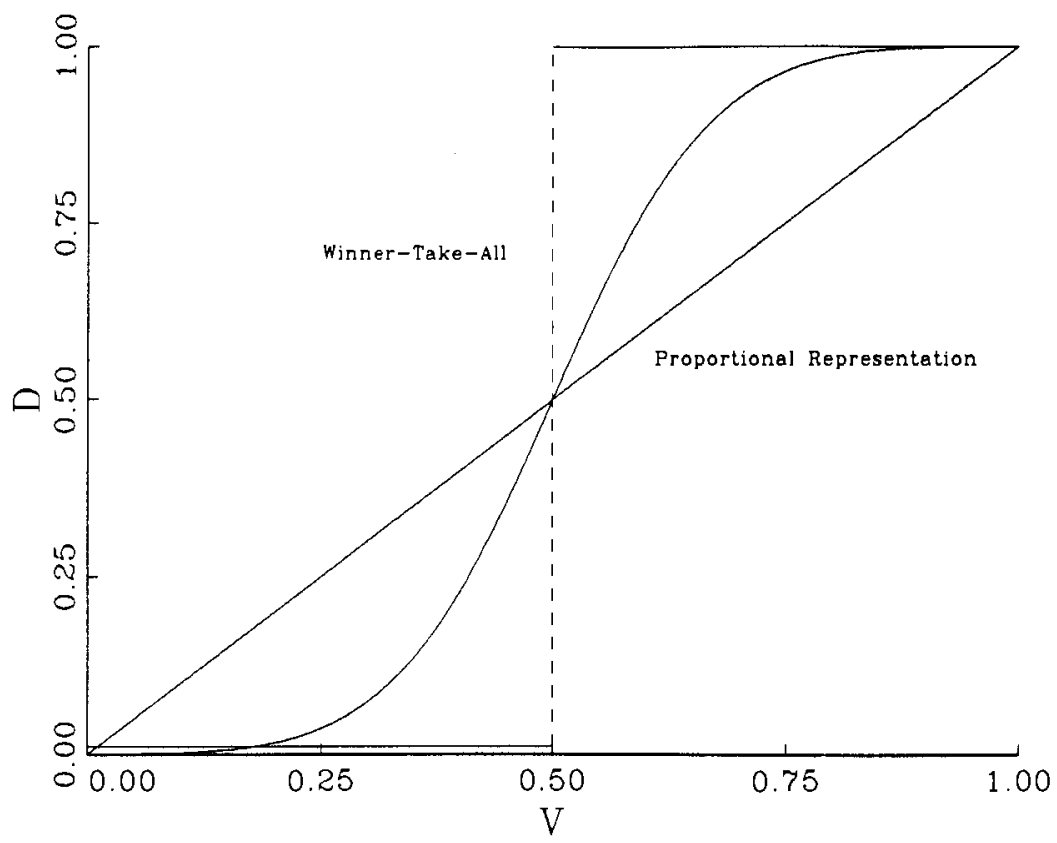


do not change their preferences but clearly do prefer one of the candidates. ${ }^{2}$ Party professionals (and likely frontrunners) prefer early nomination decisions because it seems to increase the chances for a victory in November (Lengle and Shafer 1976; Lengle 1981, 85-99; Keech and Matthews 1976; David and Ceaser 1980,69-74). One reason for this is that an early decision gives the nominee more time to prepare for the Fall campaign. An early decision is also often synonymous with a less divisive primary season (or at least with a shorter divisive season).

If PR is one's standard for fairness, then the goal of winning the White House and a responsive electoral system are incompatible. We avoid this dilemma by extending the concept of "partisan symmetry" (see Tufte 1973; Grofman 1983; Niemi 1985; King and Browning 1987; and King 1989b) to "candidate symmetry" in presidential nominations: If a candidate receives a certain allocation of convention delegates for a given proportion of votes in a state, then another candidate, if he or she were to receive the same proportion of votes, should receive the same allocation of convention delegates. This is of course a hypothetical relationship, except in the case where two candidates actually receive the same proportion of the vote, but it can be modeled (and later estimated) nonetheless.

One way to formalize the idea of candidate symmetry is to use the model studied by Theil (1969) and Qualter (1968). They portray a large variety of these symmetric curves with the following functional relationship for party (or in our case candidate) $j$ for $j=1, \ldots, J_{i}$ :

$$
E\left(D_{i j}\right)=\frac{V_{j}^{\rho}}{\sum_{m=1}^{J_{i}} V_{m}^{\rho}}
$$

This equation is a straightforward generalization of PR because if $\rho=1$, it reduces directly to equation 2 . For any value of $\rho$, this equation allocates convention delegates symmetrically and thus fairly among the candidates.

Another special case of this equation is when $\rho \rightarrow \infty$. This winner-take-all system is portrayed in figure 1 for a two-candidate contest; in this system, as soon as a candidate gets greater than $50 \%$ of the vote, he or she gets all of the convention delegates. This type of system is "fair," since it treats all the candidates equally, but since presidential nominations are generally intended to be inclusive processes, official statewide winner-take-all rules have been eliminated. However, a winner-take-all rule could also operate in practice under almost any other system if voters have homogeneous preferences and happen to always vote as a bloc.

${ }^{2}$ In the unlikely event that a majority of voters do not support a single candidate and voter preferences do not change over the course of the primary season, a responsive system will not increase the probability of wrapping up the nomination early. Note also that these are tendencies only; even a very responsive system can sometimes lead to very long nomination battles in a particular contest. 
Values of $\rho$ between one and infinity portray systems with varying degrees of responsiveness; the higher $\rho$ the more responsiveness. Figure 1 gives an example of $\rho=3$. This hypothetical electoral system is quite responsive since, near the middle of the curve, the steep slope indicates that small changes in votes for a candidate leads to relatively large changes in the allocation of convention delegates.

We also allow for candidate bias using a procedure developed by King (in press) for multiparty electoral systems. We include a separate bias parameter $\lambda_{j}$ for each candidate $j$. If the system is not biased, all these parameters will be zero; if $\lambda_{j}>0$, the system is biased in favor of candidate $j$, and $\lambda_{j}<0$ indicates bias against candidate $j$. These parameters can be incorporated into equation 3 as follows:

$$
E\left(s_{j}\right)=\frac{e^{\lambda_{3}} v_{j}^{\rho}}{\sum_{m=1}^{f_{m}} e^{\lambda_{m}} v_{m}^{\rho}}
$$

Bias is thus modeled as deviations from partisan symmetry, and both the degree of candidate bias and electoral responsiveness are key normative features of any presidential nomination system.

\section{EMpirical Estimates}

We begin our empirical investigation with an examination of the responsiveness of the parties' nomination systems. Our plan is to first present the results on aggregate responsiveness for each year and party. We then analyze the effects of formal rules on responsiveness and finally on candidate bias.

\section{Aggregate Responsiveness}

Table 1 presents estimates of the electoral responsiveness of the Democratic and Republican contests from 1976 to 1988. The Republican nomination in 1984 was uncontested, so the table includes estimates only for the remaining seven contests. These analyses reveal several striking patterns. First, the Republican presidential nominating system is more responsive than the Democratic system for every contest in our sample. This means that small changes in preferences among Republicans lead to considerably larger variations in the composition of their state delegations to the national convention. On the other hand, the composition of Democratic state delegations is allocated much more proportionally, with an average responsiveness of only 1.4. (When the candidates split the vote equally without bias, an additional percent of the vote for a candidate yields an extra $1.4 \%$ delegates for that candidate.) Whereas the highly responsive Republican system usually fosters a quick decision in their nomination contest, the Democrats had conventions that more fully represented minority interests. A candidate in the lead with momentum more quickly gathers delegates when $\rho$ is large than 
TABLE 1

Average Responsiveness in Democratic and Republican

NOMINATION CONTESTS, 1976-1988

\begin{tabular}{lcc}
\hline & $\begin{array}{c}\text { Republican } \\
\text { Contests }\end{array}$ & $\begin{array}{c}\text { Democratic } \\
\text { Contests }\end{array}$ \\
\hline 1976 & 3.641 & 1.536 \\
1980 & $(0.788)$ & $(0.188)$ \\
& 1.875 & 1.283 \\
1984 & $(0.192)$ & $(0.096)$ \\
& Uncontested & 1.353 \\
1988 & & $(0.137)$ \\
& 1.949 & 1.610 \\
& $(0.426)$ & $(0.120)$ \\
\hline
\end{tabular}

Table entries are values of $\hat{\rho}$ and "heteroskedasticity-consistent robust standard errors" in parentheses (see Gallant and White 1988).

when it is small. Of course, high values of $\rho$ need not always produce quick victories, as the 1976 Repubican contest emphasizes.

\section{Rules and Responsiveness}

In order to test the effect of rules, we use a classification scheme based on two basic choices a state has in formulating its presidential nomination rules. First, each state party chooses how its citizens will express their candidate preferences. Primaries and caucuses are the two main choices. Primary elections are held in voting booths throughout the state on a given day. Caucus meetings are conducted at the precinct or ward level, and delegates to the district level are chosen; at the district caucuses, typically two to three weeks after the precinct meetings, delegates to the state convention are chosen, and the state convention then chooses the state's delegation to the national convention.

Second, after the general choice between primaries and caucuses, a state must decide how to aggregate these expressed candidate preferences. For primaries, the aggregation rules are applied all at once either statewide or within congressional districts. For caucuses, different rules may apply to each stage of delegate selection. Most states use some form of PR rules throughout the state or a form of plurality rule applied only within each district. In the former case, if a candidate wins $40 \%$ of the statewide vote, he or she will theoretically receive $40 \%$ of the state's delegates; of course, rounding errors, candiate thresholds, and many other factors can turn PR rules into non-proportional results. In the latter case, if a candidate wins a plurality of votes in a district, he or she takes all of that district's delegates; at the 
national level, this may translate into winner-take-all representation (if all districts vote alike), an effective proportional allocation of delegates to candidates or some other value of $\rho$.

Specific voting systems are generally defined by combining variants of these two sorts of rules. Caucuses may be winner-take-all at each level or may have a proportionality component. Primaries may grant delegates to whomever wins a plurality in the district; they may allocate convention votes in proportion to the primary vote; or they may give the winning candidate a larger share of delegates than his or her vote proportion but still reserving some delegates to represent the losers. The national Democratic party now requires that all caucuses follow some sort of proportionality rule but allows primaries to use either a proportional or district-plurality rule. The Republicans impose no such uniformity on their caucuses.

These two choices-caucuses or primaries for collecting voter preferences and PR or non-PR for allocating delegates on the basis of expressed preferences-yield four basic combinations of state presidential selection rules: (1) PR primary, (2) non-PR primary, (3) PR Caucus, and (4) non-PR caucus. However, since the national Democratic party prohibits use of non-PR caucuses and since the Republicans do not usually report the complete firstround caucus vote, we combine all caucuses into a single category for further analysis in the Democratic party and use only categories (1) and (2) for the Republicans. Our data are described in the appendix.

These three categories, PR primaries, non-PR primaries, and caucuses, provide a straightforward and relatively simple guide to the types of rules used to select delegates. They are also central to the debate over party reform. Much of the reforms within the Democratic party came as a reaction against primaries and the opening of the nominating process (Ceaser 1979, chap. 6; Ranney 1975, chap. 4). Primaries are still touted as more representative than caucuses, delegate selection in the caucuses presumably remaining in the control of state party leaders (McGovern-Fraser Commission 1970, 32). Non-PR rules are likewise criticized as biased against some candidates, while PR is supposedly fair to all candidates (McGovern-Fraser Commission 1970, 44-45; Mikulski Commission 1973, 5). Changes in the delegate allocation rules have allegedly accentuated the differences between the parties. The Democrats are said to have drifted toward populist democracy while the Republicans have stuck with a system of plurality rule in congressional districts (Ceaser 1979, 276f).

Table 2 displays our estimates of the responsiveness of each party's nomination system for various delegate allocation rules. In all election years and for both parties, non-PR primaries are always more responsive than PR primaries. The effect is particularly dramatic for the Republicans. Non-PR values are all large, considerably more responsive than a proportional system. 
TABLE 2

The Effect of Rules on Responsiveness, 1976 to 1988

\begin{tabular}{cccc}
\hline & PR & Non-PR & \\
& Primaries & Caucuses \\
\hline $\begin{array}{c}\text { Republicans } \\
1976\end{array}$ & 1.235 & 6.560 & \\
& $(0.196)$ & $(1.690)$ & \\
1980 & 1.402 & 2.533 & \\
& $(0.138)$ & $(0.375)$ & \\
1988 & 1.450 & 3.103 & \\
& $(0.459)$ & $(0.347)$ & \\
Democrats & & & 0.957 \\
1976 & 1.770 & 2.402 & $(0.190)$ \\
& $(0.201)$ & $(0.726)$ & 1.439 \\
1980 & 1.192 & 1.281 & $(0.109)$ \\
1984 & $(0.062)$ & $(0.577)$ & 1.201 \\
& 1.337 & 2.810 & $(0.103)$ \\
1988 & $(0.102)$ & $(0.858)$ & 1.210 \\
& 1.431 & 2.157 & $(0.146)$ \\
\hline
\end{tabular}

All figures are estimates of $\rho$ (with heteroscedasticity-consistent standard errors in parentheses). Because Ronald Reagan ran essentially uncontested in the 1984 primaries, meaningful estimates are not possible.

However, even with PR rules, the system is consistently more responsive than strict proportionality, and significantly so in all but one case. $\rho$ is probably inflated above one because of the of the minimum vote threshold both parties impose on minor candidates.

Several authors claim that even with a proportionality requirement the caucuses remain a restrictive method of delegate selection, approximating systems of plurality rule rather than pure PR (Aldrich 1980). However, our estimates indicate that the caucuses, rather than the PR-primaries, are the bastion of proportionality in the Democratic party. In three of the four years, $\rho$ is lower for the caucuses than for non-PR and PR primaries and is not significantly different from 1.0, the case of strict empirical proportionality. Thus, despite distortions due to differential organizational strength of the candidates and aggregation from precincts up the the state level, caucuses tend to approximate proportionality more closely than the primaries do. The proportionality rule imposed by the Mikulski Commission (1973), then, seems to have worked exceedingly well in the Democratic caucuses; indeed, it has secured proportionality much better than $\mathrm{PR}$ in the primaries.

The difference between the parties in table 2 reveal that the higher aggre- 
gate responsiveness (in table 1) is mostly due to extremely high values for the Republican non-PR primaries. PR primaries are not consistently more responsive in either party and no data are available for Republican caucuses. We originally hypothesized that some of the dramatic differences between the parties were created in the early years by a few winner-take-all states, like California. However, when we reestimated the model excluding winnertake-all states, our responsiveness estimates decreased only slightly. The differences between the parties in non-PR primaries, appear to be generated by real differences between the primary electorates and party nominating systems.

\section{Candidate Bias}

We move now from a discussion of responsiveness to candidate bias. This enables us to evaluate the bias against any individual candidate as well as the inherent fairness of each party's nomination system, even after taking its level of responsiveness into account. Table 3 presents these estimates. We begin by evaluating the claims of those candidates who have specifically complained about bias in delegate selection rules, Ronald Reagan in 1976 and Jesse Jackson in 1988. Reagan claimed that had PR been used exclusively, he would have won the nomination (David and Ceaser 1980, viii, 54). Our results indicate that this complaint was unfounded. In both PR and nonPR primaries, our estimates of candidate bias in the 1976 Republican campaign are relatively precise and not significantly different from zero. Reagan thus lost a fair fight, merely failing to receive enough votes to secure a victory in delegates.

Jessie Jackson pressed his complaints even further than Reagan. He claimed that non-PR primaries are inherently biased against ideologically extreme and black candidates and convinced the Democrats to eliminate these allocation rules for 1992 (Cook 1988, 1575-77). Unlike Reagan, Jackson's complaints appear correct. The strongest bias against any candidate in any of the seven nomination contests we analyzed was that against Jackson in the 1988 non-PR primaries.

While bias does not pervade the primary election system, it certainly may frustrate or aid the bid of a particular candidate. In addition, a more general pattern that emerges from table 3 is that the eventual winner usually had an advantage. As is widely thought (Lengle and Shafer 1976), rules treat the eventual winner neutrally or favor him. Bias in favor of the eventual winner exists in at least one category of selection rules, and against at least one other candidate, in five of our seven presidential nomination contests. Bias against the eventual winner exists in only one race: the competition between Gore and Dukakis in the 1988 caucuses. The caucus system favored Gore even though Dukakis eventually won. 
TABLE 3

Candidate Bias for Republican and Democratic Primaries and Democratic Caucuses, 1976 to 1988

\begin{tabular}{|c|c|c|c|}
\hline & $\begin{array}{c}\text { PR } \\
\text { Primaries }\end{array}$ & $\begin{array}{l}\text { Non-PR } \\
\text { Primaries }\end{array}$ & Caucuses \\
\hline \multicolumn{4}{|l|}{ Republicans } \\
\hline $\begin{array}{l}1976 \\
\text { Reagan v. Ford }\end{array}$ & $\begin{array}{r}-0.042 \\
(0.058)\end{array}$ & $\begin{array}{c}0.138 \\
(0.362)\end{array}$ & \\
\hline \multicolumn{4}{|l|}{1980} \\
\hline Bush v. Reagan & $\begin{array}{c}0.044 \\
(0.111)\end{array}$ & $\begin{array}{c}-0.640 \\
(0.436)\end{array}$ & \\
\hline Anderson v. Reagan & $\begin{array}{r}-0.956 \\
(0.196)\end{array}$ & $\begin{array}{c}-0.158 \\
(0.213)\end{array}$ & \\
\hline \multicolumn{4}{|l|}{1988} \\
\hline Dole v. Bush & $\begin{array}{r}-10.071 \\
(0.650)\end{array}$ & $\begin{array}{c}-0.307 \\
(0.283)\end{array}$ & \\
\hline \multicolumn{4}{|l|}{ Democrats } \\
\hline Udall v. Carter & $\begin{array}{c}0.389 \\
(0.521)\end{array}$ & $\begin{array}{l}0.243 \\
(0.149)\end{array}$ & $\begin{array}{r}-0.070 \\
(0.194)\end{array}$ \\
\hline Wallace v. Carter & $\begin{array}{r}-0.790 \\
(0.286)\end{array}$ & $\begin{array}{c}-0.811 \\
(0.582)\end{array}$ & $\begin{array}{r}-0.113 \\
(0.036)\end{array}$ \\
\hline \multicolumn{4}{|l|}{1980} \\
\hline Kennedy v. Carter & $\begin{array}{c}0.039 \\
(0.032)\end{array}$ & $\begin{array}{c}-0.201 \\
(0.188)\end{array}$ & $\begin{array}{c}0.153 \\
(0.104)\end{array}$ \\
\hline \multicolumn{4}{|l|}{1984} \\
\hline Hart v. Mondale & $\begin{array}{r}-0.168 \\
(0.279)\end{array}$ & $\begin{array}{c}-0.542 \\
(0.270)\end{array}$ & $\begin{array}{r}-0.096 \\
(0.087)\end{array}$ \\
\hline Jackson v. Mondale & $\begin{array}{c}-0.225 \\
(0.161)\end{array}$ & $\begin{array}{c}0.319 \\
(0.538)\end{array}$ & $\begin{array}{r}-0.363 \\
(0.085)\end{array}$ \\
\hline \multicolumn{4}{|l|}{1988} \\
\hline Jackson v. Dukakis & $\begin{array}{r}-0.283 \\
(0.309)\end{array}$ & $\begin{array}{r}-10.567 \\
(0.364)\end{array}$ & $\begin{array}{r}-0.120 \\
(0.119)\end{array}$ \\
\hline Gore v. Dukakis & $\begin{array}{c}0.025 \\
(0.123)\end{array}$ & $\begin{array}{c}0.047 \\
(0.387)\end{array}$ & $\begin{array}{c}0.185 \\
(0.079)\end{array}$ \\
\hline Gephart v. Dukakis & $\begin{array}{c}-0.069 \\
(0.136)\end{array}$ & $\begin{array}{r}-0.586 \\
(0.153)\end{array}$ & $\begin{array}{c}0.140 \\
(0.165)\end{array}$ \\
\hline
\end{tabular}

Tabular entries are estimates of $\lambda_{j}$ (with heteroscedasticity-consistent standard errors in parentheses). No estimates are available for the Republican party caucuses since vote totals are not reported. Because Ronald Reagan ran essentially uncontested in the 1984 primaries, meaningful estimates are not possible. 


\section{CONCLUSIONS}

The political struggle for party reform has done more than pique the curiosity of academic researchers; it has brought political scientists into an important debate and enabled them to have real policy impact (Kirkpatrick, Malbin, Mann, Penniman, and Ranney 1980; Kirkpatrick 1976; Ranney 1975; 1987; Sanford 1981). Political scientists have advised the parties and helped reformers sort out the consequences of rules changes. Unfortunately, academic research has remained unable to predict or even systematically evaluate the precise consequences of the rules changes. Case studies, descriptions, and histories have laid out a rich picture of the political struggle for party reform, but they provide little unambiguous evidence about the validity of our intuitions. ${ }^{3}$ Our formal statistical model enables us to formalize some of the normative arguments in this literature and to estimate from existing data two features of the underlying presidential selection systemresponsiveness and candidate bias.

We found that specific candidate allocation procedures have markedly different effects. PR rules produce a system with much lower responsiveness than primaries with non-PR rules, but even the imposition of PR does not mean that convention delegates are allocated in strict proportion to expressed voter preferences. Indeed, and contrary to conventional wisdom, PR rules operated much more effectively in the Democratic caucuses than it did in that party's primaries.

We also discovered significant and systematic differences between the two parties selection systems. Whereas the Republican system was uniformly more responsive to changes in their voters' preferences, the Democratic system represented minorities more fully. Furthermore, much of this difference is located within the non-PR primaries. Since these differences between the two parties were found within rules categories, they cannot be explained simply by the mix of PR and plurality rules chosen by the two parties; instead, fundamental differences in composition and geographic distribution of the Republican and Democratic electorates also generate differences between the two systems.

Manuscript submitted 23 January 1989

Final manuscript received 10 September 1989

\section{APPENDIX}

We collected data from two sources. The vote percents and delegate counts are the tallies presented in the Congressional Quarterly Weekly Re-

${ }^{3}$ Indeed, even the leading text on the subject reaches similar conclusions (Polsby and Wildavsky 1984, 107-108). 
ports (annual reports). Unfortunately, as Aldrich (1980, appendix) notes, first-round vote totals are not reported along with delegate allocations for the Republican caucuses in 1976, and the same is true for 1980. Reagan ran essentially uncontested in 1984, and, although a portion of the 1988 results are available, there are too many exceptions and problems to make them useful compared with the Democratic results. The delegate allocation rules are taken from the reports of the Democratic and Republican National Committees. The DNC publishes a report entitled "Delegate Selection Rules for the Democratic National Convention" for each convention. The RNC has a similar report entitled "Delegate Selection Procedures."

Details on estimation can be found in King (in press). The log-likelihood we estimated is as follows:

$$
\begin{aligned}
& \ln L\left(\rho, \lambda_{2}, \ldots, \lambda_{j} \mid D\right)= \\
& \sum_{i=1}^{n}\left\{\sum_{j \in E_{i}} D_{i j}\left[\lambda_{j}+\rho \ln \left(v_{i j}\right)-\ln \left(\sum_{k \in E_{i}} e^{\lambda_{k}+\rho \ln v_{i k}}\right)\right]\right\}
\end{aligned}
$$

where $E_{i}$ is the set of candidates competing in state $i$. Maximizing this equation with respect to $\rho$, and $\lambda_{2}, \ldots, \lambda_{J}$ gives the values of these parameters that are most likely to have given us the data we observed (King 1989a). Tables 1-3 report these maximum likelihood estimates, along with heteroscedasticity-consistent standard errors (Gallant and White 1988). A computer program is available from the authors.

\section{REFERENCES}

Aldrich, John H. 1980. Before the Convention. Chicago: University of Chicago Press.

Bartels, Larry. 1988. Presidential Primaries and the Dynamics of Public Choice. Princeton, NJ: Princeton University Press.

Brady, Henry E., and Richard Johnston. 1987. "What's the Primary Message: Horse Race or Issue Journalism?" In Media and Momentum, ed. Gary Orren and Nelson Polsby. Chatham, NJ: Chatham House.

Brady, Henry E., and Steven Ansolabehere. 1988. "The Nature of Utility Functions in Mass Publics." American Political Science Review 83: 143-63.

Ceaser, James W. 1979. Presidential Selection: Theory and Development. Princeton, NJ: Princeton University Press.

Cook, Rhodes. 1988. "Was This Any Way to Nominate a President?" Congressional Quarterly Weekly Report June 11:1575-77.

David, Paul T., and James W. Ceaser. 1980. Proportional Representation in Presidential Nominating Politics. Chalottesville, VA: University of Virginia Press.

Gallant, A. Ronald, and Halbert White. 1988. A Unified Theory of Estimation and Inference for Nonlinear Dynamic Models. Oxford: Basil Blackwell.

Geer, John G. 1986. "Rules Governing Presidential Primaries.” Journal of Politics 48: 1006-25.

Grofman, Bernard. 1983. "Measures of Bias and Proportionality in Seats-Votes Relationships." Political Methodology 9: 295-327. 
Keech, William R., and Donald R. Matthews. 1976. The Party's Choice. Washington, DC: Brookings Institution.

King, Gary. in press. "Electoral Responsiveness and Partisan Bias in Multi-Party Democracies." Legislative Studies Quarterly, XV(2).

King, Gary, 1989a. Unifying Political Methodology: The Likelihood Theory of Statistical Inference. New York: Cambridge University Press.

King, Gary. 1989b. "Representation Through Legislative Redistricting: A Stochastic Model." American Journal of Political Science 33(4): 787-824.

King, Gary, and Robert X. Browning. 1987. "Democratic Representation and Partisan Bias in Congressional Elections." American Political Science Review: 1251-76.

Kirkpatrick, Jean. 1976. The New Presidential Elite: Men and Women in National Politics. New York: Russell Sage Foundation.

Kirkpatrick, Jean, Michael Malbin, Thomas Mann, Howard Penniman, and Austin Ranney. 1980. The Presidential Nominating Process: Can It Be Improved? Washington, DC: American Enterprise Institute.

Lengle, James, and Byron Shafer. 1976. "Primary Rules, Political Power, and Social Change," American Political Science Review $70: 25-40$.

Lengle, James. 1981. Representation and Presidential Primaries: The Democratic Party in the Post Reform Era. Westport, CT: Greenwood.

McGovern-Fraser Commission. 1970. Mandate for Reform. Washington, DC: Democratic National Committee.

Mikulski Commission. 1973. Democrats All, Report of the Commission on Delegate Selection and Party Structure. Washington, DC: Democratic National Committee.

Niemi, Richard G. 1985. "The Relationship Between Votes and Seats: The Ultimate Question in Political Gerrymandering." UCLA Law Review 33: 185-212.

Polsby, Nelson W., and Aaron Wildavsky, 1984. Presidential Elections: Strategies of Electoral Politics, 6th ed. New York: Charles Scribners and Sons.

Qualter, Terence H. 1968. "Seats and Votes: An Application of the Cube Law to the Canadian Electoral System." Canadian Journal of Political Science 1 : 336-44.

Ranney, Austin. 1975. Curing the Mischiefs of Faction: Party Reform in America. Berkeley, CA: University of California Press.

Ranney, Austin. 1987. "Farewell to Reform-Almost." Society 24:29-38.

Sanford, Terry. 1981. A Danger of Democracy. Boulder, CO: Westview Press.

Theil, Henri. 1969. "The Desired Political Entropy." American Political Science Review 63: 521-25.

Tufte, Edward. 1973. "The Relationship Between Seats and Votes in Two-Party Systems." American Political Science Review 67: 540-54.

Stephen Ansolabehere is assistant professor of political science, University of California, Los Angeles, CA 90024-1472.

Gary King is professor of government, Department of Government, Harvard University, Cambridge, MA 02138. 